\title{
The Accountability of Military Commander for the Forces Doing Gross Violations of Human Rights
}

\author{
Mokhamad Ali Ridho, \\ Researcher, Doctoral Student of Faculty of law, University of Jember \\ Prof. Dr. M. Arief Amrullah, S.H., M.Hum., \\ Promotor \\ Dr. Heribertus jaka Triyana, S.H., LL.M., M.A, \\ Co-Promotor \\ Dr. Aries Harianto, S.H., M.H. \\ Reviewer of article
}

\begin{abstract}
Command responsibility occurs due to gross violation of human rights committed by subordinates under the effective control. It develops in doctrines and practices which then normatively institutionalize in International Law and National Law. In the National Law, the Command responsibility is regulated in Article 42 of Act No. 26 of 2000 concerning Human Rights Courts of State Gazette Number 208. Military Commander or a person who effectively acts as a Military Commander may be responsible for crimes that are within the Jurisdiction of Human Rights Courts carried out by forces under Command, and effective courts, and The criminal offense is a result of improper control, namely: the Military Commander or someone knows that the force is committing or has just committed a gross violation of Human Rights and that the Military Commander or someone does not take appropriate and necessary actions under his power to prevent or stop the act or to submit the matters to the competent authorities for investigation and prosecution. In the military organization of combat units, the composition of the military commander began with the Unit Commander, Platoon Commander, Company Commander, Battalion Commander, Brigade Commander, Division Commander and Commander of the Army Strategic Command (Pangkostrad) for the Kostrad ranks. In the Special Forces Command (Kopassus) ranks there are known General Commander (Danjen) Kopassus, Group Commander (Dangroup) and so on. For Territorial units, starting from the Military District Commander (Danramil), Military Regions Commander (Dandim), Military Resort Commander (Danrem) and Territorial Military Commander (Pangdam). The Army Chief of Staff (Kasad) Supervise the command ranks of the Army, including the Chief of the Navy (Kasal) and Chief of Staff of the Air Force (Kasau), and the Indonesian National Army (TNI) Commander as the command holder for all Forces, the Army, Navy and Indonesian Air Force.
\end{abstract}

Keywords: Command responsibility of gross violation of human rights

DOI: $10.7176 / \mathrm{JLPG} / 85-13$

Publication date:May $31^{\text {st }} 2019$

\section{Introduction}

The responsibility of a commander for all activities under his unit is comprehensive. The commander issues decisions, permits, policies and orders and simultaneously oversees their implementation. It is common in the military life, that a commander is responsible for the actions taken by his subordinates in in carrying out their duties. The commander's responsibility to control and supervise the behavior of soldiers under his control is the principle of responsible military life. ${ }^{1}$

Giving assignments to hold military command over a unit or force are accompanied by extensive authority and high responsibility. However, a commander is not necessarily blamed for every violation or crime done by his forces. But if he allows the occurrence of crimes committed by his subordinates and the crime is carried out systematically, takes considerable period of time, and occurs in various places within his area of responsibility, but he does not take any appropriate and necessary actions to prevent, stop and take action against the perpetrators of the crime, the commander is liable for crimes committed by subordinates under his control and command based on the doctrine of command responsibility. ${ }^{2}$

Command responsibility is closely related to the power possessed by a commander to issue orders to his subordinates. The authority of a commander to issue orders arises from his position as the commanding officer in

\footnotetext{
${ }^{1}$ Natsri Anshari, Tanggung Jawab Komando Menurut Hukum Internasional dan Hukum Nasional Indonesia. Jurnal Hukum Humaniter, Fakultas Hukum Trisakti, Jakarta, Vol 1, No 1, p. 45

${ }^{2}$ Ibid, p. 46
} 
his unit. For the commander, giving orders is a very important controlling mechanism to express the will of the commander. ${ }^{1}$

The international community is concerned on the great crimes that occurred in the 20th century which caused the killing of millions of human beings and millions of other people experienced traumatic suffering due to torture, rape, kidnapping, forced resettlement, destruction of arbitrary property and various other heinous acts. Therefore the 20th century is commonly referred to as the century of Human Tragedy. By the various vicious events, only a few perpetrators of crimes can be submitted to the Court, it is because most of these crimes are committed by those who held the power in the region / country, so the court is powerless to carry out their duties. ${ }^{2}$

This apprehensive condition has prompted countries in the world to hold a meeting which intends to find a way to prosecute the perpetrators of crimes against humanity through an international judiciary. The four crimes that are considered the most serious are of international concern, namely the crime of genocide (a crime which is the annihilation of ethnic / ethnic groups), crimes against humanity, war crimes, and the crime of aggression. ${ }^{3}$ These matters mentioned pushed the countries in the world making an international judicial body specifically for crimes on humanity, known as the International Criminal Court / ICC.

The establishment of the ICC was based on the Rome Statute, which was made by countries in the world before the UN diplomatic conference in Rome in 1998, which contained the basis for the formation of the ICC. The formation of the ICC is also motivated by the wishes of the international community, which are formal, independent, permanent and are not ad hoc, such as the current international criminal justice bodies, such as the post-World War II international crime court namely the International Military Tribunal (IMT) known as the Nuremberg Tribunal in 1945, the International Military Tribunal for the Far East (IMTFE) in 1946, the International Criminal Tribunal for former Yugoslavia (ICTY) and International Criminal Tribunal for Rwanda (ICTR). ${ }^{4}$

The establishment of the Human Rights Court in Indonesia seems to oppose the will of the international community to try suspects / defendants in the International Court for gross violation of human rights. It also wants to dismiss the notion that Indonesia is unable or unwilling to prosecute suspects / defendants accused of committing such serious human rights violations.

Prof. Muladi stated that the formation of the Human Rights Court seemed to be under pressured by the international community, because previously there were no signs that the Indonesian Government would try those suspected of committing gross human rights violations. Therefore, at the beginning the formation of the Human Rights Court was formulated in the form of a Government Regulation in Lieu of Law (Perpu), which apparently contain many weaknesses so that it could not be approved by the DPR to become a law and in a short time, it was changed to Act No. 26 of 2000 concerning the Human Rights Court. ${ }^{5}$

\section{Research Method}

This research is a normative legal research, i.e., a process to find the rule of law, legal principles, and legal doctrines in order to answer the legal issues faced. ${ }^{6}$ Normative legal research always takes the issue of law as a norm system that is used to provide prescriptive justification about a legal event, so normative legal research makes the norm system the center of its study. ${ }^{7}$ The norm system simply is a system of rules. ${ }^{8}$ In relation to normative research, various approaches can be used, namely; (i) statute approach; (ii) conceptual approach; (iii) analytical approach; (iv) historical approach; (v) philosophical approach; and (vi) case approach ${ }^{9}$

The legal material is collected by inventory and review of laws and regulations, reviewing the literature as primary and secondary materials by processing legal materials. Furthermore, doing inventory, identification and categorization on the collected legal materials. Secondary legal materials are collected using a card system method such as quote cards, overview cards and reviews or analysis cards.

The main purpose of the analysis of legal material is to find the meaning of terms used in the legislation conceptually, as well as knowing its application in the practice and legal decisions. It was done through two checking process. First, researchers try to obtain new meanings contained in the relevant legal rules. Second, examine legal terms in practice through analysis of legal decisions.

The legal definition occupies an important place, both symbolized in the words used and arranged in a

\footnotetext{
${ }^{1}$ Ibid, p. 46

${ }^{2}$ Abdul Harid Semendawan, Ancaman Amerika Terhadap Mahkamah Pidana Internadional, dalam www.elsam.or.id.

${ }^{3}$ Jerry Fowler, Kata Pengantar Statuta Roma Tentang Mahkamah Pidana Internasional : Keadilan Bagi Generasi Mendatang, (Jakarta: ELSAM, 2000), p. vii

${ }^{4}$ Romli Atmasasmita, Pengadilan Pidana Internasional dan Rancangan Undang-Undang Hak Asasi Manusia, www.sekitarkita.com

${ }^{5}$ Komariah Emong Supardjaja, Mekanisme Nasional Untuk Penyelesaian Pelanggaran Hak Asasi Manusia yang Berat, dalam Jurnal HAM,

Vol. 2 No. 2, November 2004, (Jakarta: Komisi Nasional Hak Asasi Manusia, 2004), p. 145

${ }^{6}$ Peter Mahmud Marzuki, Penelitian Hukum, (Jakarta: Prenada Media Grup, 2011), p. 11

${ }^{7}$ Mukti Fajar ND dan Yulianto Achmad, Dualisme Penelitian Hukum Normatif dan Empiris, (Yogyakarta: Pustaka Pelajar, 2010), p. 36

${ }^{8}$ Ranuhandoko, Terminologi Hukum, (Jakarta: Grafika, 2003), p. 419

${ }^{9}$ Johnny Ibrahim, Teori dan Mtodologi Penelitian Hukum Normatif, Cetakan Keenam, (Malang: Penerbit Bayumedia Publishing, 2012), p. 300
} 
formulation of rules. Word or definition contained in a formula or rule of law does not have meaning. Possibly, the meanings that given to a word or definition are not representative anymore, either by the times or to fulfill the interests of an all-inclusive system, so that new meaning or definitions are needed, because the word meaning accuracy is needed for legal certainty. Meanwhile, finding meaning in words or legal definitions is a legal scientific activity from its normative aspects.

\section{Results and Discussion}

Based on the background and problems previously described, the results of the research and discussion described as the following:

\subsection{Ratio Legis of Criminal Liability of a Military Commander for Gross Violation of Human Rights Conducted by the Subordinates}

The Ad Hoc Human Rights Court in Indonesia has implemented the responsibility of commander in prosecuting gross violations of human rights in East Timor, where most of the perpetrators were prosecuted under Article 42 paragraph (1) of the Act Number 26 of 2000 concerning the Human Rights Court. The defendants who were tried in the court did not only consist of military officials but also the governor and regents.

Although this doctrine originates from humanitarian legal instruments where this law only applies to situations of armed conflict, it also applies in cases not relating to armed conflicts, such as in cases of genocide crimes and crimes against humanity that occur outside armed conflict. Article 1 of the 1984 Anti-Torture Convention also adheres to the principle of responsibility of the superior.

Article 42 paragraph (1) of the Act Number 26 of 2000 concerning Human Rights Courts, Military Commander or persons acting as military commanders. The military commander is a member of the armed forces assigned to lead one or more units in the armed forces. The commander has the authority to issue orders directly to his subordinates or to the units below them and oversee the implementation of these orders. In a chain of command there are generally more than one commander. The chain of command consists of team commanders, platoon commanders, company commanders, battalion commanders, brigade commanders, division commanders and other top commanders. In the literature of international humanitarian law, international legal instruments, Indonesian legislation as well as in decisions on war crimes cases, there are no restrictions on the degree to which a commander can be blamed on jurisprudence of various international courts in various violations of the laws of war indicating there are no restrictions on the level of accountability of military commanders. Thus, understanding in the military regarding the limitation of a commander's responsibility to only two steps up or down (two-step up two-step down) is unfounded and is not in accordance with the international and national jurisprudence.

The people acting as military commanders are those who are not members of the armed forces but because of their de facto powers and authority, they are able to command and control their armed forces. In certain countries a head of state / government or other political figure may have command authority. For example, the President of the Republic of Indonesia based on the 1945 Constitution was the highest authority for the Army, Navy and Air Force. The position of the President as the supreme leader of the armed forces (now the Indonesian National Army and the Police of the Republic of Indonesia) is ruling as an effective authority, not just symbolic. There are indeed two views regarding the position of the President (Head of State) as the highest leader of the army. The first view regards it as symbolic to show that the military is under the control of a civilian government. Another opinions stated that the position of the President as the supreme leader of the armed forces or army is not only symbolic but effective. The president with his own power can mobilize the army to take certain actions. ${ }^{1}$

Article 42 of the Act Number 26 of 2000 uses the term "could" and removes "criminal" while in the original text Article 28 (a) The Rome Statute uses the term "shall be criminally responsible" which is said to be "must be liable criminally". This can lead to multiple interpretations for law enforcement because it can be interpreted that a commander is not "always" responsible and does not always have to be criminally accountable for the actions of his subordinates. The use of the term "can" and the removal of the word "criminal" is not in line with the intent of Article 28 (a) of the Rome Statute, also with Article 42 (b) of Act Number 26 of 2000 jo. Article 28 (b) Rome Statute.

\subsection{Criminal Accountability of Military Commander for the Subordinates Conducting Gross Violations to Human Rights based on the Court Verdict}

The duty and authority possessed by the Human Rights Court according to Article 4 of the Act Number 26 of 2000 is to examine and decide cases of gross violations of human rights. The gross violations of human rights, according to Article 7, includes crimes of genocide and crimes against humanity. The procedural law used in the trial is the Criminal Procedure Code as stipulated in Article 10 of Act Number 26 of 2000.

The genocide referred to in Article 8 of Act Number 26 of 2000 include:

"... every act carried out with the intention of destroying all or part of a national group, race, ethnic group,

\footnotetext{
${ }^{1}$ Bagir Manan, Lembaga Kepresidenan, (Yogyakarta: FH UII Press, 2003), p. 26
} 
religious group, by: (a) killing group members; (b) causing severe physical or mental suffering to group members; (c) creating group living conditions that will result in physical destruction; (d) enforcing actions aimed at preventing births in groups; or (e) forcibly transferring children from certain groups to other groups ".

The crimes against humanity as stipulated in Article 9 are:

"... one of the acts carried out as part of a widespread or systematic attack that was directed at the civilian population, in the form of: (a) murder; (b) destruction; (c) slavery; (d) forced eviction or transfer of population; (e) deprivation of liberty or arbitrary deprivation of other physical freedoms that violate (principles) the basic provisions of international law; (f) torture, rape, sexual slavery, forced prostitution, forced pregnancy, sterilization or forced sterilization or other forms of sexual violence; (h) persecution of a particular group or association based on the common understanding of politics, race, nationality, ethnicity, culture, religion, gender or other reasons that have been universally recognized as being prohibited under international law; (i) forced disappearance; or (j) the crime of apartheid ".

Attacking the civilians according to Act Number 26 of 2000 is a series of actions carried out against civilians as a continuation of the ruling policy or policies relating to the organization. The types of crimes including genocide and crimes against humanity are adopted from the provisions of the Rome Statute of the International Criminal Court. From this explanation, it can be concluded that the elements of crime in Act Number 26 of 2000 are equated with the regulations in the Rome Statute, including widespread and systematic elements.

Dellictum of command responsibility is regulated in Article 42 paragraph (1) of Act Number 26 of 2000 , namely: Military commander or someone who effectively acts as a military commander can be accountable for criminal acts within the jurisdiction of the human rights court. which is under effective command and control, or under effective authorization and control, and the crime is a result of improper control of the troops, namely:

a. the military commander on the basis of the current circumstances should know that the force is committing or has just committed a gross violation of human rights; and

b. the military commander does not take appropriate action and under his power is required to prevent or to stop the act or to give the perpetrator to the competent authority for investigation and prosecution.

The concept of the command responsibility, as well as the concept of crimes against humanity, also experienced a distortion in the formulation of the Act Number 26 of 2000. The definition of command responsibility in Article 42 paragraph (1) states:

"Military command or someone who effectively acts as a military command can be accountable for crimes within the jurisdiction of the human rights court, carried out by forces under effective command and control ..."

The above definition, which uses the word "could" and not "should" or "shall", implicitly confirms that command responsibility in cases of gross violations of human rights regulated through this Act is not a things that are automatic and mandatory. This article explicitly reinforces the notion of crimes against humanity in Article 9 which tends to be directed at perpetrators directly in the field. Thus the Public Prosecutor must be able to demonstrate and prove the existence of "Urgency" to try the commanders in charge and not only field actors.

Furthermore, Article 42 paragraph (1) (a) requires that the person in charge of the command "should know that the force is committing or has just committed gross human rights violations". In fact, the source of the specific article, namely Article 28 paragraph (1) (a) of the Rome Statute expressly states that the military commander should "know that the forces are committing or want to commit a crime ..."

This distortion means ignoring the obligation of the holder of command responsibility to prevent the occurrence of crime. Although in Article 42 paragraph (1) (b) this ignorance is corrected by the phrase "the military command does not take appropriate and necessary actions within the scope of his power to prevent and stop the act, ..." but there are no definite definitions and limitations about what is appropriate and needs to be done by the person in charge of command.

In addition, the implications of the article for the court is to emphasize the focus on the process, whether the actions taken are appropriate or not, whether it is necessary or not (obligation of conduct), and automatically ignoring the fact whether the actions taken by the responsible person succeed prevent and stop crimes or not (obligation of result). In fact, in addition to having to be responsible as direct actor, advocate or co-participant, a superior should also be liable criminally for dereliction of duty and negligence. International customary law standards for dereliction and negligence in the broadest sense state that a superior is criminally responsible if: (1) he should have had knowledge that a violation of law has been or is happening, or will occur and carried out by his subordinates ; (2) he has the opportunity to take action, and (3) he fails to take corrective action that should be carried out according to circumstances that existed or occurred at that time. The case whether someone is "supposed to know" must be tested according to the circumstances that occur and by seeing other people / officials who are equal to the charged.

The commander's responsibility for all activities in his unit is comprehensive. ${ }^{1}$ The general responsibility of

\footnotetext{
${ }^{1}$ Natsri Anshari, Tanggung Jawab Komando menurut Hukum Internasional dan Hukum Nasional Indonesia, Jurnal Hukum Humaniter, Volume
} 
a command implies the responsibility of each command at each level or to his superiors to: first, carry out the main duties of his command or unit. Second, the use of the most effective all available resources. The executor of command responsibility is a commander as someone who has command authority and responsibility for the implementation of unit duties under his command. While command has two meanings. First, the authority and power granted to an officer to lead, coordinate and control troops. Second, orders given by a commander or superior directly to the unit or subordinate to carry the order.

Position as a superior charged him heavy responsibilities and duties. In addition to the general responsibility of a command, a military commander or other person in leading position can be criminally accountable for unlawful acts committed by his subordinates. ${ }^{1}$

The criminal liability can emerge either from positive actions from the superior which is known as direct command responsibility or from culpable omissions known as indirect command responsibility or command responsibility strictu sensu. Thus, a superior can be responsible not only if he orders, incites, or plans a criminal offense committed by his subordinates, but also if he fails to take action to prevent or stop the crime committed by his subordinates. ${ }^{2}$

The responsibility of a commander for crimes committed by soldiers under his control needs element of involvement, connection, knowledge or intent of a commander with a crime committed by his subordinates.

A commander's criminal responsibility is based on breach of duty. There are two reasons to be considered as a basis for judging that a violation of duty has resulted in a crime. First, violations of the task or service must have a direct relationship or be the main cause of the emergence of crime. Second, the commander must have the authority and power to prevent the crime. ${ }^{3}$

The legal principle regarding command responsibility is an important principle in the administration of courts against crimes involving military and civilian leaders. This principle of law was adopted in the ICTY Court which tried the cases of Zdravko Music, Zejnil Delalic, Hazim Delic and Esad Lando, who were allegedly responsible for crimes committed at the Celebici camp. The doctrine of command responsibility was also used in the ICTR Court to prosecute perpetrators of crimes in Rwanda. Jean Paul Akayesu is one of those charged with the doctrine of command responsibility. And there are many other cases carried out by political and military leaders who can be accountable through the principle of responsibility of commanders accused of violations of international crimes or in the Indonesian context known as gross violations of human rights.

The responsibility of commanders is also contained in the international humanitarian law instruments such as the Hague Convention of 1907, Additional Protocol I of the Conventions of Geneva of 1949 and 1977, Statute of ICTY (International Criminal Tribunal for the former Yugoslavia, Statute of ICTR (International Tribunal Criminal for Rwanda), and also the Rome Statute of $1998 .{ }^{4}$

The regulations regarding the responsibilities of the commander in each convention and the statutes of the court have different contents. There are some experts stated that the commander's responsibility is the failure to act from a commander or superior who is asked to be accountable, and others also argue that the commander's responsibility is the silence of a commander or superior.

The Hague Convention of 1907 is an international agreement that first determines that a superior is responsible for violations of the law committed by his subordinates. Followed by the 1949 Geneva Convention which assigned a commander to protect prisoners of war, prisoners of camp and civilians during the war. 1977 Additional Protocol I shows that command responsibility has wider scope. It regulates the failure of a commander to act, and expressly places the duties and obligations of a commander.

The Statutes of the ICTY, ICTR and the ICC explain that there are no restrictions regarding the implementation of the doctrine of commander's responsibility. Anyone who holds the same power and command functions as military commander without having to have a military rank, owns and carries the same responsibility as a military commander.

The application of the doctrine of commander's responsibility shows that it is not only a military commander who can be accountable for the doctrine of commander's responsibility, but also a civilian superior whether he holds de jure or de facto power. Thus the implementation of commander's responsibility in the Zdravko Music case is the responsibility of contemporary commanders in which their decisions indicates that the ICTY can provide clear elements and more explicit boundaries.

The Indonesian government's decision to try gross violations of human rights in East Timor after the 1999 referendum was a possible effort in international law. Through Act No. 26 of 2000 concerning the Human Rights Court and Presidential Decree No. 53 of 2001 an ad hoc court was formed against gross violations of human rights that occurred in Tanjung Priok in 1984 and in East Timor in 1999. This effort was carried out by Indonesia as a

\footnotetext{
1,2005 , p. 45

${ }^{1}$ Ilias Bantekas, The Contemporary Law of Superior Responsibility, 93 AJIL 573. 576, 1999

${ }^{2}$ Ibid

${ }^{3}$ William G. Eckhardt, Command Criminal Responsibility: A Plea for a Workable Standard. 97 Military Law Riview, 1982, 5

${ }^{4}$ Arie Siswanto, Hukum Pidana Internasional, (Yogyakarta: ANDI, 2015), p. 269
} 
form of Indonesia's responsibility and efforts made by the Indonesian government in order to resolve the case at the national level.

As one mechanism in resolving violations of international law, the settlement through a national mechanism is expected to be an effective mechanism, in addition to international and hybrid mechanisms. It is based on the desire to realize universal justice. International mechanisms is only a complement to the enforcement system through a national mechanism. International mechanisms are implemented when national mechanisms experience failure, inability or unwillingness to uphold justice. Based on the idea that international courts will never be able to try all international cases, the main responsibility is still for the state to prosecute and punish the most serious crimes under international law. ${ }^{1}$

Settlement through national mechanisms has become an option, the government's decision to establish a court at the national level is also the right choice. However, the ad hoc court that began in March 2002 showed inconsistency from the Indonesian government. As many as 12 sessions at this trial, out of 18 defendants, only 6 (six) were found guilty. There are various factors, such as weaknesses in the Act Number 26 of 2000 , lack of professionalism of law enforcement officers, the light punishments that are often below the minimum sentence stipulated in the law, and the defendant convicted remains free when there is no appeal decision, and so are the reasons for the parties to say the court has failed.

The notion that international law is a weak law because it cannot be enforced, and being obscured due to the developments in the international community. Violations of International Law are no longer charged only to the state, but also to individuals. This is consistent with the developments after World War II related to the recognition of several entities other than the state as subjects of international law. ${ }^{2}$ In line with the recognition of individuals as subjects of international law, for violations of international law categorized as international crime, individual criminal liability is acknowledged.

Gross violations of human rights within the scope of international law are international crimes, which are considered as common enemies of human (hostis humanis generis), because they are related to the interests of the international community as a whole. Therefore, it becomes the obligations of all human beings (obligatio erga omnes) to resolve it legally by sentencing the perpetrators fairly. ${ }^{3}$ The perpetrators of international crimes will be accountable for universal jurisdiction. Universal jurisdiction is an international legal response to the phenomenon of impunity for perpetrators of serious crime violations under international law, for perpetrators freely conduct activities in various parts of the world, without any lawsuits. ${ }^{4}$

The desire of the international community for criminal accountability of individuals has existed, but is institutionalized after World War II, namely the existence of the International Military Tribunal at Nuremberg 1945 and the International Military Tribunal for Far East 1946. After the two tribunals, the concept of individual criminal responsibility is increasingly recognized in international law. In the tribunal, the concept of individual responsibility for three types of crimes was categorized as international crimes, namely crimes against peace, war crimes and crimes against humanity. ${ }^{5}$

Although the two tribunals are often said to be courts of war-winning parties for victory justice, some matters contribute to the development of international law. In individual criminal responsibility, a person cannot take refuge behind the state, even though at that time he was carrying out state duties. ${ }^{6}$

The success of the Nuremberg and Tokyo Tribunals motivates the formulation of an ad hoc tribunal in resolving cases that occurred in Yugoslavia and Rwanda. Based on United Nations Security Council Resolution (hereinafter abbreviated as UN Security Council) 827 dated May 2, 1993 an International Criminal Tribunal for Former Yugoslavia (ICTY) was formed and based on UNSC Resolution 955 November 8, 1994 the International Criminal Tribunal for Rwanda (ICTR) was formed

The next development in the context of upholding international crimes, a hybrid tribunal combines local / national and international elements. This form of court is an answer to the experience of previous courts, i.e., "gaps" between national and international courts. For national courts, the main problem is a lack of credibility and incompetence, while international courts have limitations in terms of authority and mandate. Nowadays, four mixed courts have been established, three established between 1999 and 2001 in East Timor (the Special Panels for Serious Crimes of the District Court of Dili), in Kosovo (Regulation 64 "Panels in the Courts of Kosovo), in

\footnotetext{
${ }^{1}$ Michael Cottier, "War Crimes in International Law: An Introduction", Jurnal Hukum Humaniter, Vol.1, No.1, Juli 2005, Pusat Studi Hukum Humaniter dan HAM (terAS), (Jakarta: FH Universitas Trisakti, 2005), p. 37

${ }^{2}$ Rein A. Mullerson, "Human Rights and the Individual as a Subject of International Law: A Soviet View", European Journal of International Law (EJIL), Vol.1 No. 1, (Badia Fiesolana: European University Institut, 1990), p. 34

${ }^{3}$ Asmara Nababan, "Penyelesaian Pelanggaran Hak Asasi Manusia yang Berat: Belajar dari Pengalaman", Jurnal HAM Komisi Nasional Hak Asasi Manusia, Vol.2 N0.2, Nopember 2004, (Jakarta: Komisi Nasional Hak Asasi Manusia, 2004), p. 94

${ }^{4}$ Ridarson Galingging, "Universal Jurisdiction in Absentia Congo v. Belgium, ICJ, Feb.14, 2002”, Jurnal Hukum Internasional Vol. 1 No. 2, Agustus 2002, (Jakarta: Lembaga Pengkajian Hukum Internasional Fakultas Hukum Universitas Indonesia, 2002), p. 103

${ }^{5}$ Edoardo Greppi, "The Evolution of Individual Criminal Responsibility under International Crime", International Review of the Red Cross No.835, 1999, hal. 531-534.

${ }^{6}$ Ibid, p. 535
} 
Sierra Leone (Special Court of Sierra Leone) and in Cambodia (the Extraordinary Chambers in the Courts of Cambodia). ${ }^{1}$

The culmination of the international community's success in law enforcement efforts for violating international law, especially international crimes with individual criminal responsibility, occurred in 1998. At that time, in Rome July 17, 1998, 120 countries agreed to sign the Rome Statute of 1998, which marked the establishment of International Criminal Court (ICC) which is a permanent international criminal court. Although the ICC is a permanent court, as stated in the Preamble of the 1998 Rome Statute, emphasizing that the international criminal court established under the Statute shall be complementary to national criminal jurisdiction.. This complementary principle strengthens and complements national mechanisms, while respecting the sovereignty of each country. It is due to the fact that every country still has the same opportunity to regulate its national mechanism for violations of international law which includes international crimes.

\subsection{Criminal Liability of a Military Commander for Forces Conducting Gross Violations of Human Rights Ahead}

Article 1 paragraph (3) of the 1945 Constitution stipulates that Indonesia is a state of law, meaning that the law should be applied as a framework / foundation in regulating and resolving various legal problems in social life. Thus, of course no institution or person, whether military (TNI), police (Polri), or other civilians are free from the legal provisions and laws that apply for committing a crime in general, including violations of human rights

According to Bambang Sunggono and Aries Harianto, a state of law should at least have the following three main characteristics:

1. The recognition and protection of human rights that contain equality in the political, social, economic, legal, cultural and other fields;

2. A free courts, impartial and are not influenced by other powers; and

3. Upholding the principle of legality. ${ }^{2}$

Various efforts to provide protection for human rights in various parts of the world including Indonesia, are not easy to do, it requires a long process in which at least related to the three main variables that must be considered. These three variables are international dynamics; existing legal instruments; and how to determine the approach to the legacy of the past. ${ }^{3}$

Attempts at deprivation of life including other acts of violence on human dignity and values are a form of human rights violations, if it is carried out arbitrarily and without legal justification and applicable legislation. In the history of legal development, perpetrators of human rights violations, especially military superiors, can be prosecuted and tried based on the principle of command responsibility. Command responsibility is a form of criminal responsibility of military commanders, police superiors and other civilian superiors for crimes on human rights violations in Indonesia committed by the subordinates or those are under their command or effective control.

Human rights violations in the view of experts can be resolved through court mechanisms, and truth commissions, to resolve human rights violations with the courts intended to uphold the rule of law and justice. The Act No. 26 of 2000 has a mandate to resolve human rights violations in Indonesia, with its authority to prosecute violations of western human rights in Indonesia, but on the basis of das sein, no single violation of gross human rights has been sanctioned by the Human Rights Court, which legally means there has never been a human rights violation, whereas in the das sollen regulated what constitutes a gross human rights violation as outlined in Act No. 26 of 2000, which covers acts against humanity and genocide. With the elements of the crime stipulated in the Act No. 26 of 2000.

Human rights violations by both the Military Commander and Civil Superiors, as well as suspects / defendants from members of the military and civilians, who were tried under Act No. 26 of 2000 concerning the Human Rights Court, in fact many were released or found not guilty. Likewise the problem of criminal responsibility of military commanders based on Article 129 and Article 132 of the Military Criminal Code (KUHPM) states:

1. Article 129 of KUHPM: "The army forces who intentionally, either by exceeding the limits of their power, or out of the interests of service, instruct a subordinate to act, to not do or to let anything happen, are sentenced with imprisonment for two years and eight months".

2. Article 132: "A military superior who intentionally allows a subordinate to commit a crime, or who is a witness of a crime committed by a subordinate who deliberately does not take any acts of violence that are required according to his abilities".

In relation with Article 42 of Act No. 26 of 2000 concerning Human Rights Courts, there are articles that

\footnotetext{
${ }^{1}$ Andrey Sujatmoko, "Pengadilan Campuran ("Hybrid Tribunal”) sebagai Forum Penyelesaian atas Kejahatan Internasional", Jurnal Hukum Humaniter, Vol.3, No.5, Oktober 2007, (Jakarta: Pusat Studi Hukum Humaniter dan HAM (terAS), FH Universitas Trisakti, 2007), p. 977978.

${ }^{2}$ Bambang Sunggono dan Aries Harianto, Bantuan Hukum dan Hak Asasi Manusia, (Bandung: CV. Mandar Maju, 1994), p. 130

${ }^{3}$ Sigit Riyanto, Penegakan HAM Di Indonesia Beberapa Catatan Kritis, Majalah Mimbar Hukum No.38/VI/2001 FH-UGM, (Yogyakarta: 2001), p. 53
} 
regulate the responsibility of military commanders or civilian superiors whose criminal threats are higher:

1. The military commander or someone who effectively acts as a military commander should be accountable for criminal acts within the jurisdiction of the Human Rights Court, which are carried out by forces under his effective command and control, and the crimes are the results of improper control of forces, namely:

a. the military commander or someone either knew, or owing to the circumstances, should have known that the forces is committing or has just committed a gross violation of human rights; and

b. the military commander or someone failed to take all necessary action within his power to prevent or stop the act or to submit the matter to the competent authorities for investigation and prosecution.

2. A Superior, both the police and other civilians, is criminally reliable for the gross violations of human rights committed by his subordinates under his effective power and control, due to his improper control:

a. the supervisor knows or consciously ignores information that clearly shows that subordinates are committing or have just committed gross human rights violations; and

b. the superior does not take necessary actions under his power and authority to prevent or stop the act or to submit the matter competent authority for and prosecution.

Criminal sanction formulated based on Article 129 of the Criminal Procedure Code is at least two years and eight months, while Article 36 to Article 40 of Act No. 26 of 2000 concerning the Human Rights Court, the defendant may be sentenced to death or life imprisonment for a maximum of 25 (twenty five) years and a minimum of 5 (five) years. The command responsibility is not the commander's responsibility for personal crimes, but it is the commander's responsibility for crimes committed by his subordinates or responsibility for decisions made by commander that may give impacts to others. To be accountable for crimes committed by soldiers under his command and control there needs to be an element of involvement, connection, knowledge or intent of a commander with a crime committed by his subordinates. ${ }^{1}$

According to Muladi, the main elements of command responsibility can be identified, namely: (1) the relationship between superiors and subordinates; (2) the supervisor has the knowledge or possible to know that it has happened or is being done; and (3) superiors failed to take necessary and reasonable steps to prevent criminal acts or punish perpetrators. Relations between superiors and subordinates can be de jure de facto. ${ }^{2}$

Violations of the duty or service must have a direct relationship or be the main cause of emergence of crime. In this case, the crime will not occur if there is no violation of service obligations. Then, the commander must have the authority and power to prevent the occurrence of the crime. ${ }^{3}$

Article 42 paragraph (1) letter (a) also requires the person in charge of command to "should know that these forces are carrying out or have just committed serious human rights violations." Even though the source of the specific article, namely Article 28 paragraph (1) letter (a) The Rome Statute expressly states that the military commander should "know that these forces are carrying out or intending to commit crimes."

The responsibility of the military commander based on the hierarchy of command positions within the Indonesian National Armed Forces organizational structure is that each military commander is only responsible for the actions taken by his subordinates directly. This is in accordance with the principle, the Direct Superior acts as the Superiors who have the authority to punish (ANKUM). For example, the Battalion Commander was the direct superior of Company Commander, while the Company Commander was the direct superior of the Platoon Commander, and the Platoon Commander was the direct superior of the Team Commander. The Team commander is directly responsible for the soldiers under his command. But the involvement of the Battalion Commander, Company Commander, and Platoon Commander could have occurred if they fulfilled the elements of criminal acts as referred to in Article 129 and Article 132 of the Military Criminal Code, in Article 36 to Article 42 of Act Number 26 of 2000 concerning Human Rights Courts (HAM).

\section{Conclusions}

Regarding the previous analysis and discussion, the following conclusions are presented as answers to the problems in this study:

a. The ratio legis of the criminal responsibility of a military commander to the subordinates committing gross violations of Human Rights exists due to the relationship between superiors and subordinates, this criminal responsibility continues to develop in practice and doctrine which then institutionalizes normatively in the international law such as International Criminal Tribunal for the former Yugoslavia (ICTY), International Criminal Tribunal for Rwanda (ICTR) and International Criminal Court (ICC) and in national law regulated in Article 42 paragraph (1) Act number 26 of 2000 concerning the Human Rights Court namely military commander or someone who effectively acting as a military commander can be held accountable for crimes within the jurisdiction of the Human Rights Court, which are carried out by forces or people under his effective command and control.

\footnotetext{
${ }^{1}$ Muladi, Demokrasi, Hak Asasi Manusia, dan Reformasi Hukum di Indonesia, (Jakarta: The Habibie Centre, 2002), p. 280

${ }^{2}$ Ibid., p. 283

${ }^{3}$ Natsir Anshari, Op. Cit., p. 49
} 
b. Each military commander can be criminally responsible for forces committed gross human rights violations because the military commander knows or owing to the current circumstances, should have known that his forces are committing or have just committed gross human rights violations and failed to take all necessary and reasonable actions within his power to prevent or stop their commission or to submit the matter to the competent authorities for investigations and prosecutions.

c. The ideal criminal responsibility of a military commander for forces committing gross human rights violations that the responsibility of a Military Commander based on the Commander's hierarchy of positions in the TNI Organizational Structure is that each Military Commander is only responsible for the actions taken by his subordinates. This is in accordance with the principle of Direct Superiors acting as the Superiors who have the authority to punish $(A N K U M)$. For example, the Battalion Commander as $A N K U M$ toward all Battalion forces. And based on the principle of "not being convicted without crimes", as well as the principle of legality which states that an action cannot be condemned, except based on the strength of existing criminal legislation provisions.

\section{Recommendations}

a. The application of criminal responsibility for gross violations of human rights as stipulated in national law and international law, depends on the willingness of the state as a violator. Therefore, in order the application of criminal liability can be legally binding, a more binding instrument is needed in the form of an International Treaty.

b. The effective settlement of gross human rights violations is by doing criminal proceedings on people committing gross human rights violations, then to the Military Commander as a criminal responsibility for gross human rights violations committed by Forces under his control.

c. In the practice, in the cases of Serious human rights violations, military commanders who are prosecuted depend on the current circumstances so there is no clear measure of the extent to which the Military Commander is accountable for cases of gross violations of human rights. It is based on article 42 paragraph (1) of Act Number 26 of 2000 concerning the Human Rights Court by mentioning the Military Commander or someone who effectively acts as the Military Commander, so that it requires to amend Article 42 paragraph (1) by mentioning the Military Commander has the right to punish (ANKUM) forces committing serious human rights violations.

\section{References}

Books:

Abdulajid, Syawal dan Ashar, Pertanggungjawaban Pidana Komando Militer Pada Pelanggaran Berat HAM, Yogyakarta: Laksbang Pressindo, 2010

Abdussalam, Hukum Pidana Internasional, Bandung: Restu Agung, 2006

Abidin, Andi Zainal, Hukum Pidana I, Jakarta: Sinar Grafika, 1983

Ali, Achmad, Menguak Teori Hukum dan Teori Peradilan, Cet IV, Jakarta: Prenada Media Goup, 2012

Arief, Barda Nawawi, "Masalah Pemidanaan sehubungan Perkembangan Delik-delik Khusus dalam Masyarakat Modern”, Kertas Kerja, pada Seminar Perkembangan Delik-delik Khusus dalam Masyarakat yang mengalami Modernisasi BPHN-FH UNAIR Surabaya, Tanggal 25-27 Februari 1980, Bandung: Bina Cipta, 1982 , Bunga Rampai Kebijakan Hukum Pidana, Semarang: Galia, 2001

Atmasasmita, Romli, Reformasi Hukum, Hak Asasi Manusia dan Penegakan Hukum, Bandung: Mandar Maju, 2001

, Kapita Selekta Hukum Pidana Internasional Jilid ke-2, Bandung: CV. Utomo, 2004

, Sistem Peradilan Pidana Kontemporer, Bandung: Citra Aditya Bakti, 2010

Fowler, Jerry, Kata Pengantar Statuta Roma Tentang Mahkamah Pidana Internasional : Keadilan Bagi Generasi Mendatang, Jakarta: ELSAM, 2000

Fuady, Munir, Dinamika Teori Hukum, Jakarta: Ghalia Indonesia, 2007

Gillies sebagaimana dikutip M. Arief Amrullah, Politik Hukum Pidana, Perlindungan Korban Kejahatan Ekonomi Di Bidang Perbankan Dalam Perspektif Bank Sebagai Pelaku (Offender), Yogyakarta: Genta Publishing, 2015

Hamel, Van sebagaimana dikutip Eddy O.S. Hiariej, Prinsip-Prinsip Hukum Pidana, Yogyakarta: Cahaya Atma Pusaka, 2014

Hamzah, Andi, Sistem Pidana dan Pemidanaan Indonesia, Jakarta: Pradnya Paramita, 1993 , Hukum Acara Pidana Indonesia, Jakarta: Sinar Grafika, 2005

Harkrisnowo, Harkristuti, Tindak Pidana dalam Perspektif Kitab Undang-Undang Hukum Pidana, dalam Pidana Islam di Indonesia, Peluang Prospek dan Tantangan, Jakarta: Pustaka Firdaus, 2001

Hart, H.L.A., Konsep Hukum (The Concept of Law), Bandung: Penerbit Nusa Media, 2011

Hiariej, Eddy O.S, Prinsip-Prinsip Hukum Pidana, Yogyakarta: Cahaya Atma Pustaka, 2014 
HR, Ridwan, Hukum Administrasi Negara, Yogyakarta: UII Press, 2002

HS, Salim dan Erlies Septiana Nurbani, Penerapan Teori Hukum Pada Penelitian Disertasi Dan Tesis, Jakarta: PT Rajagrafindo Persada, 2010

Huda, Chairul, Dari Tiada Tanpa Kesalahan Menuju Kepada Tiada Pertanggungjawaban Pidana Tanpa Kesalahan, Jakarta: Prenada Media, 2006

Huijbers, Theo, Filsafat Hukum dalam Lintas Sejarah, Yogyakarta: Kanisius, 1982 , Filsafat Hukum, Yogyakarta: Kanisius, 1991

Ibrahim, Johnny, Teori dan Mtodologi Penelitian Hukum Normatif, Cetakan Keenam, Malang: Penerbit Bayumedia Publishing, 2012

Juwana, Hikmahanto, Konsep Tanggung Jawab Pimpinan dalam Hukum Pidana Internasional, Jakarta: Fakultas Hukum UI, 2006

Kaligis, O.C., Perlindungan Hukum Atas Hak Asasi Tersangka, Terdakwa, dan Terpidana, Bandung: PT. Alumni, 2006

Kartanegara, Satocid, Hukum Pidana Kumpulan Kulian, Buku I, Jakarta: Balai Lektur Mahasiswa, tt

Kelsen, Hans, Teori Hukum Murni, Dasar-dasar Ilmu Hukum Normatif, Bandung: Nusa Media, 2014

Keraf, Sonny, Etika Bisnis Tuntunan dan Relevansinya, Yogyakarta: Kanisius, 1998

Khadduri, Majjid, The Islamic Conception of Justice, Baltimore and London : The Johns Hopkins University Press, 1984

Kusumaatmadja, Mochtar, Fungsi dan Perkembangan Hukum dalam Pembangunan Nasional, Bandung: Bina Cipta, t.t

Lamintang, P.A.F. dan Djisman Samosir, Delik-Delik Khusus Kejahatan Yang Ditujukan Terhadap Hak Milik dan Lain-Lain Hak Yang Timbul Drai Hak Milik, Bandung: Penerbit Tarsito, 1981

Lamintang, P.A.F., Dasar-Dasar Hukum Pidana Indonesia, Bandung: Citra Aditya Bakti, 1997

Manan, Bagir, Lembaga Kepresidenan, Yogyakarta: FH UII Press, 2003

Marzuki, Peter Mahmud, Penelitian Hukum, Edisi Revisi, Jakarta: Penerbit Kencana Prenada Media Group, 2005 , Pengantar Ilmu Hukum, Jakarta: Kencana, 2008

, Penelitian Hukum, Jakarta: Prenada Media Grup, 2011

Moelijono, Anton M., et.al, Kamus Besar Bahasa Indonesia, Jakarta: Balai Pustaka, 1998

Moeljatno, Asas-Asas Hukum Pidana, Jakarta: Rineka Cipta, 1993

, Perbuatan Pidana dan Pertanggungjawaban dalam Hukum Pidana, Yogyakarta: Seksi Kepidanaan

Fakultas Hukum Universitas Gadjah Mada, 2000

Muladi dan Barda Nawawi Arief, Teori-Teori dan Kebijakan Pidana, Bandung: Alumni, 1982

Muladi dan Dwidja Priyatno, Pertanggungjawaban Pidana Korporasi, Jakarta: Kencana Prenada Media Group, 2010

Muladi, Lembaga Pidana Bersyarat, Bandung: Alumni, 1992

, Kapita Selekta Sistem Peradilan Pidana, Semarang: Badan Penerbit Universitas Diponegoro, 1995

, Statuta Roma Tahun 1998 tentang Mahkamah Pidana Internasional Dalam Kerangka Hukum Pidana Internawsiona dan Implikasinya Terhadap Hukum Pidana Nasional, Bandung: Alumni, 2001

2002

Demokrasi, Hak Asasi Manusia, dan Reformasi Hukum di Indonesia, Jakarta: The Habibie Centre,

Hak Asasi Manusia, Politik dan Sistem Peradilan Pidana, (Jakarta: Sinar Grafika, 2002

Pound, Roscoe, Tugas Hukum, terjemahan Moh. Radjab, Jakarta: Bharata, 1965

Prodjodikoro, Wirjono, Asas-asas Hukum Pidana di Indonesia, Bandung: Refika Aditama, 2011

Prodjohamidjojo, Martiman, Memahami Dasar-Dasar Hukum Pidana Indonesia 2, Jakarta: Pradnya Paramita, 1997

Purwoleksono, Didik Endro, Hukum Acara Pidana, Surabaya: Airlangga University Press, 2015

, Hukum Pidana, Surabaya: Airlangga University Press, 2016

Rahardjo, Satjipto, Ilmu Hukum, Bandung: Citra Aditya Bakti, 1996

, Ilmu Hukum, Bandung: Alumni, 1998

Rato, Dominikus, Filsafat Hukum Mencari: Memahami dan Memahami Hukum, Yogyakarta: Laksbang Pressindo, 2010

Reksodiputro, Mardjono, Hak Asasi Manusia Dalam Sistem Peradilan Pidana, Edisi Pertama, Jakarta: Pusat Pelayanan Keadilan dan Pengabdian Hukum Universitas Indonesia, 1994

Remellink, Jan, Hukum Pidana (Komentar Atas Pasal-Pasal Terpenting Dari KUHP Belanda dan Padanannya Dengean KUHP Indonesia, Jakarta: Gramedia Pustaka Utama, 2003

Rizki, Rudi M., Catatan Mengenai Tanggung Jawab Negara atas Pelanggaran Berat HAM, dalam Mieke Komar Kantaatmadja dan Etty R. Agoes, Mochtar Kusumatmadja: Pendidik dan Negarawan, Bandung: Alumni, 1999

Saleh, Roeslan, Perbuatan Pidana dan Pertanggungjawaban Pidana Dua Pengertian Dasar dalam Hukum Pidana, 
Cetakan Ketiga, Jakarta: Aksara Baru, 1983

, Perbuatan Pidana dan Pertanggungjawaban Pidana; Dua Pengertian Dasar dalam Hukum Pidana,

(Jakarta: Aksara Baru, 1983

1985 Beberapa Catatan Sekitar Perbuatan dan Kesalahan dalam Hukum Pidana, Jakarta: Aksara Baru,

, Pikiran-pikiran tentang Pertanggungan Jawab Pidana, Jakarta: Ghalia Indonesia, 1986

Stelsel Pidana Indonesia, Jakarta: Aksara Baru, 1987

Sianturi, SR, Hukum Pidana Militer di Indonesia, Jakarta: Alumni Ahaem Petehaem, 1985

, Asas-Asas Hukum Pidana di Indonesia dan Penerapannya, Jakarta: Alumni Ahaem-Petehaem, 1996

Sihombing, Parlaungan, Opini Hukum dan Operasi, Jakarta: Kanisius, 2000

Soekamto, Soerjono, Faktor-Faktor Yang Mempengaruhi Penegakan Hukum, Jakarta: Raja Grafindo Persada, 2007

Soekanto, Soerjono dan Sri Mamudji, Penelitian Hukum Normatif, Jakarta: Penerbit Rajawali Pers, 2011

Soesilo, R., Kitab Undang-Undang Hukum Pidana (KUHP) Serta Komentar-Komentarnya Lengkap Pasal demi Pasal, Bogor: Politeia, 1988

Sudarto, Suatu Dilema dalam Pembaharuan Sistem Pidana Indonesia, Semarang: FH-UNDIP, 1979 Hukum dan Perkembangan Masyarakat, Bandung: Sinar Baru, 1983

, Hukum Pidana dan Perkembangan Masyarakat, Bandung: Sinar Baru, 1983

Kapita Selekta Hukum Pidana, Bandung: Alumni, 1986

, Hukum dan Hukum Pidana, Bandung: Alumni, 1998

Sujatmoko, Andrey, Tanggung Jawab Negara Atas Pelanggaran Berat HAM: Indonesia, Timor Leste dan lainnya, Jakarta: PT Gramedia Widiasarana Indonesia, 2005

Suryokusumo, Sumaryoso, Studi Kasus Hukum Internasional, Jakarta: Rajawali, 2001

Syafa'at, Muchamad Ali, Tindak Pidana Teror: Belenggu Baru bagi Kemerdekaan, dalam F. Budi Hardiman, et.al., Terorisme Definisi, Aksi dan Regulasi, Jakarta: Imparsial, 2003

Tanya, Bernand L., dkk, Teori Hukum. Strategi Tertib Manusia Lintas Ruang dan Generasi, Yogyakarta: Genta Publishing, 2009

\section{Legislations}

1945 Constitution of the Republic of Indonesia

Criminal Code (KUHP)

The Act Number 39 of 1999 concerning Human Rights

The Act Number 26 of 2000 concerning the Human Rights Court

The Act Number 3 of 2002 concerning National Defense

The Act Number 34 of 2004 concerning the Indonesian National Army

The Act Number 12 of 2005 concerning Ratification of the International Covenant on Civil and Political Rights, State Gazette of the Republic of Indonesia of 2005 Number 119, Supplement to the State Gazette of the Republic of Indonesia Number 4558

Decree of the TNI Commander Number: Kep 22 / VIII / 2005 dated August 10, 2005 concerning the Indonesian National Army Soldier's Regulations

\section{Papers/Journals}

Anshari, Natsri, Tanggung Jawab Komando Menurut Hukum Internasional dan Hukum Nasional Indonesia. Jurnal Hukum Humaniter, Fakultas Hukum Trisakti, Jakarta, Vol 1, No 1

Arief, Barda Nawawi, "Perkembangan Sistem Pemidanaan di Indonesia" Makalah Bahan Pentaran Nasional Hukum Pidana dan Kriminologi keXI Tahun 2005, Surabaya: FH Ubaya-Aspehupiki, Hotel Hyat, 13-16 Maret 2005

Arinanto, Satya, Pengadilan HAM dalam Perspektif Nasional dan Internasional, Makalah, 12 April 2000

Bantekas, Ilias, The Contemporary Law of Superior Responsibility, 93 AJIL 573. 576, 1999

Cottier, Michael, "War Crimes in International Law: An Introduction", Jurnal Hukum Humaniter, Vol.1, No.1, Juli 2005, Pusat Studi Hukum Humaniter dan HAM (terAS), Jakarta: FH Universitas Trisakti, 2005

Doktrin TNI AD Kartika Eka Paksi

Falaakh, M. Fajrul, "Reformasi Ketatanegaraan, Separasi TNI-Polri dan Rekonstruksi Peradilan Militer," Background Paper untuk Review UU Peradilan Militer 1997, Jakarta Hotel Crown Plaza, 8-10 September 2002

Galingging, Ridarson, "Universal Jurisdiction in Absentia Congo v. Belgium, ICJ, Feb.14, 2002", Jurnal Hukum Internasional Vol. 1 No. 2, Agustus 2002, Jakarta: Lembaga Pengkajian Hukum Internasional Fakultas Hukum Universitas Indonesia, 2002

Greppi, Edoardo, “The Evolution of Individual Criminal Responsibility under International Crime”, International 
Review of the Red Cross No.835, 1999

Kasim, Ifdhal (Ed), Dimensi-dimensi HAM pada Administrasi Keadilan

Linton, Suzzanah, New Approaches to International Justice in Cambodia and East Timor, International Review of the Red Cross, Vol. 84, No. 845, Maret 2002

Mahfud MD, Moh., "Penegakan Hukum dan Tata Kelola Pemerintahan yang Baik", Seminar Nasional "Saatnya Hati Nurani Bicara” yang diselenggarakan oleh DPP Partai HANURA. Jakarta, 8 Januari 2009

Moeljatno, Perbuatan Pidana dan Pertanggungjawaban dalam Hukum Pidana, pidato diucapkan pada Upacara Peringatan Dies Natalies VI Universitas Gadjah Mada, tanggal 19 Desember 1955, Jakarta: Bina Aksara, 1985

Mudzakir, "Posisi Hukum Korban Kejahatan dalam Sistem Peradilan Pidana”, Disertasi, Jakarta: Program Pascasarjana FH UI, 2001

Muladi, Kursus HAM untuk Pengacara X, dalam Materi "Pengadilan Hak Asasi Manusia", 2005

"Pembaharuan Hukum Pidana Materiil Indonesia" Makalah pada Kongres Asosiasi Pengajar Hukum Pidana dan Kriminologi (Aspehupiki) dan Seminar "Pengaruh Globalisasi Terhadap Hukum Pidana dan Kriminologi Menghadapi Kejahatan Transnasional,” Bandung 16-18 Maret 2008

Nababan, Asmara, "Penyelesaian Pelanggaran Hak Asasi Manusia yang Berat: Belajar dari Pengalaman", Jurnal HAM Komisi Nasional Hak Asasi Manusia, Vol.2 N0.2, Nopember 2004, Jakarta: Komisi Nasional Hak Asasi Manusia, 2004

Riyanto, Sigit, Penegakan HAM Di Indonesia Beberapa Catatan Kritis, Majalah Mimbar Hukum No.38/VI/2001 FH-UGM, Yogyakarta: 2001

Setiyono, "Pertanggungjawabanan Komando (Command Responsibility) Dalam Pelanggaran HAM Berat (Studi Kasus Kejahatan Terhadap Kemanusiaan di Indonesia)”, Disertasi, Semarang: Universitas Diponegoro 2010

Sihombing, PLT, Pertanggungjawaban komando. Jurnal HAM Komisi Hak Asasi Manusia. Vol. 2, No. 2, November 2004

Sisworo, Soejono Koesomo, Mempertimbangkan Beberapa Pokok Pikiran Pelbagai Aliran Filsafat Hukum Dalam Relasi dan Relevansinya Dengan Pembangunan/Pembinaan Hukum Indonesia, Pidato Pengukuhan Guru Besar, Semarang: UNDIP, 30 Maret 1989

Sondakh, Devy, Aspek-aspek Hukum Humaniter dalam Kejahatan Perang yang dilakukan oleh Anggota Dinas Angkatan Laut dalam Konflik Internasional. Volume 4 No.7. Jakarta: Penerbit Pusat Studi Hukum Humaniter dan HAM Universitas Trisakti, 2008

Sujatmoko, Andrey, "Pengadilan Campuran ("Hybrid Tribunal") sebagai Forum Penyelesaian atas Kejahatan Internasional”, Jurnal Hukum Humaniter, Vol.3, No.5, Oktober 2007, Jakarta: Pusat Studi Hukum Humaniter dan HAM (terAS), FH Universitas Trisakti, 2007

Supardjaja, Komariah Emong, Mekanisme Nasional Untuk Penyelesaian Pelanggaran Hak Asasi Manusia yang Berat, dalam Jurnal HAM, Vol. 2 No. 2, November 2004, Jakarta: Komisi Nasional Hak Asasi Manusia, 2004 